\title{
Engineering Example of Compact Type Sewage Treatment Plant
}

\author{
Weijian Zhou ${ }^{1,2}$, Wenzhong Liang ${ }^{1,2}$, Yining Ding ${ }^{1,2}$, Yutao Lei $^{2}$, Zhihua Pang $^{1,2}$, Zhipeng Zhuang ${ }^{1,2, *}$ \\ ${ }^{1}$ Guangzhou Huake Environmental Protection Engineering Co., Ltd., Guangzhou 510655, China \\ ${ }^{2}$ South China Institute of Environmental Sciences, the Ministry of Environment Protection of PRC, Guangzhou 510655, China
}

\begin{abstract}
Considering the land shortage features of a given district in Hangzhou city, the High-sludge sedimentation tank + denitrification filtering tank + nitrification filtering tank + cloth media filtering tank process is adopted for purification treatment. When the system (with the treatment scale of $15,000 \mathrm{~m}^{3} / \mathrm{d}$ ) runs for 60 days, the average removal rate of COD and ammoniacal nitrogen are $86 \%$ and $96 \%$ respectively and the effluent quality reach the quasi grade IV standard.
\end{abstract}

\section{Introduction}

With the rapid expansion of urban scale and the sharp increase of population size, the land resources in the urban district becomes very scarce. The situation under which the sewage treatment plant seizes the land index with the human being occurs in many places. In order to ensure the up-to-standard discharge of sewage treatment, the local government requires and entrusts the Designer to design a set of compact type sewage treatment plant with the floor area of no more than $2,500 \mathrm{~m}^{2}$ and the handling capacity of $15,000 \mathrm{~m}^{3} / \mathrm{d}$. For the main water quality indicators of the effluent, please refer to the IV level standard provided in the Environmental Quality Standards for Surface Water (GB3838-2002). As per the above requirements, it is determined to adopt the High-sludge sedimentation tank + denitrification filtering tank + nitrification filtering tank + cloth media filtering tank process after the demonstration and comparison.

Both the denitrification filtering tank and nitrification filtering tank feature the small floor area, good effluent quality, high handling efficiency, low total investment of the project and other advantages $[1,2]$. In recent years, they are widely applied to standard improvement modification works. The High-sludge sedimentation tank is a new-style coagulative precipitation tank which has been rapidly promoted in recent years, which features the high surface load and low SS in the effluent, and other advantages[3]. The cloth media filtering tank features the small floor area, clear effluent and other advantages[4]. The author introduces the process flow of the sewage treatment plant, design of main structures and buildings, operation effect and operation cost.

\section{Sewage Handling Capacity and Water Quality Features}

The handling capacity of the sewage treatment plant in design is $15,000 \mathrm{~m}^{3} / \mathrm{d}$. As per the sewage water quality data provided by the Client, the sewage is dominated by the sanitary sewage. As the project location is at the densely-populated region, greater difficulty exists if the effluent must conform to the IV level surface water standard and the floor area is $2500 \mathrm{~m}^{2}$ only. The influent and effluent quality of this project in design are as shown in Table 1.

Table 1. Influent and Effluent Quality Indicators (in $\mathrm{mg} / \mathrm{L}$ )

\begin{tabular}{cccc}
\hline Item & $\mathrm{COD}$ & $\mathrm{NH}_{3}-\mathrm{N}$ & $\mathrm{TP}$ \\
\hline Inflow & $\leq 350$ & $\leq 30$ & $\leq 6.0$ \\
Effluent & $\leq 30$ & $\leq 1.5(5.0)^{*}$ & $\leq 0.3$ \\
\hline
\end{tabular}

Note: *the numerical value outside the bracket is the control index at the water temperature of more than $12^{\circ} \mathrm{C}$, while the numerical value inside the bracket is the control index at the water temperature of less than or equal to $12^{\circ} \mathrm{C}$.

\section{Sewage Treatment Process}

\subsection{Process Selection}

There are many treatment processes of sanitary sewage, including the common methods, such as AAO, oxidation ditch and etc.[5]. However, such methods cannot be used here due to the larger floor area. After the comprehensive consideration of floor area, effluent effect and other factors, this project adopts the High-sludge sedimentation tank + denitrification filtering tank + nitrification filtering tank + cloth media filtering tank process.

\footnotetext{
*Corresponding author's e-mail: 13570325177@163.com
} 


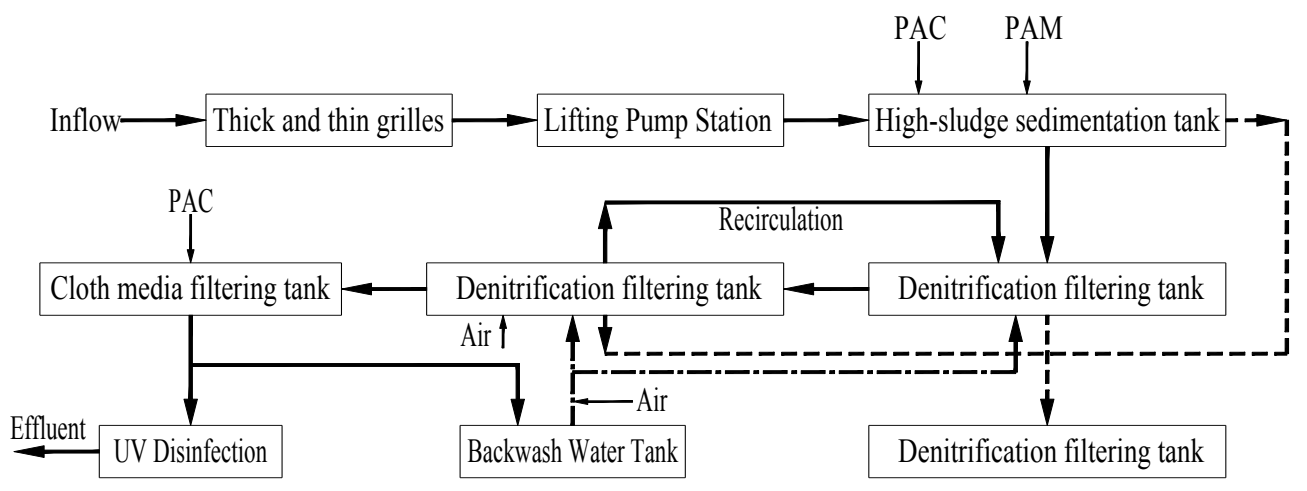

Figure 1. Sewage Treatment Process Flow Chart

The process flow description is as follows: high efficiency physicochemical reaction + deep carbonization denitrification + intensified effluent.

(1) High efficiency physicochemical reaction: the sewage firstly passes through the thick grille where the larger floating matter and suspended matter will be removed. Then, it enters into lifting pump station where it will be lifted via the pump and enter into the fine grille tank where the floating matter and suspended matter with the equivalent diameter exceeding $5 \mathrm{~mm}$ will be blocked, so as to protect the normal operation of subsequent equipment and handling units. After passing through the thick and thin grilles, the sewage will enter into the High-sludge sedimentation tank. Under the action of coagulation, flocculation and settling, most SS \& TP, and partial COD \& BOD in the sewage will be removed, while the effluent flows to the subsequent handling units. After the intensified physicochemical reaction, the contents of COD, SS, TP, and $\mathrm{NH}_{3}-\mathrm{N}$ may be reduced by $30 \%-50,80 \%-90 \%$ and $85 \%-95 \%$, and $10 \%-15 \%$.

(2) Deep carbonization denitrification: upon the normal operation, the DO value of denitrification filtering tank shall be less than $0.2 \mathrm{mg} / \mathrm{L}$. Under the anaerobic conditions, the denitrifying bacteria will reduce the $\mathrm{TN}$ into nitrogen. After the treatment of denitrification filtering tank, the effluent will self-flow to the lower level nitrification filtering tank. Under the condition that DO value exceeds $2 \mathrm{mg} / \mathrm{L}$, the aerobe and nitrifying bacteria are effectively removed, and the BOD and $\mathrm{COD}$ are further degraded into the $\mathrm{CO}_{2}, \mathrm{H}_{2} \mathrm{O}$ and other small molecule inorganics, while the $\mathrm{NH}_{3}-\mathrm{N}$ is converted into the nitrate and nitrite. Thus, it is removed. The effluent of nitrification filtering tank will be backflowed to the front end of denitrification filtering tank via the lift of pump to have the denitrification. In this manner, the $\mathrm{NH}_{3}-\mathrm{N}$ is effectively removed and the effluent is discharged into the intermediate clean-water tank. Now, after the deep carbonization denitrification, the COD of the effluent may be reduced by about $90 \%$, while the SS may be reduced and kept at a lower level, and the TP may be reduced by $60 \%-70 \%$. In addition, the $\mathrm{NH}_{3}-\mathrm{N}$ may be reduced by $90 \%-95 \%$, while the effluent quality index may reach the IV standard.

(3) Intensified effluent: after the deep filtering of cloth media filtering tank, the COD, TP and $\mathrm{NH}_{3}-\mathrm{N}$ of the effluent may be reduced by about 5\%,5\%-10\% and $15 \%-30 \%$ separately. The effluent will realize the up-to-standard discharge after being subject to the ultraviolet disinfection.

\subsection{Main structures and design parameters}

(1) Grille type grit chamber. Its front end is used to remove the smaller suspended matter and floating matter, while its rear end is used to remove the fine sand with the density of more than $2.65 \mathrm{t} / \mathrm{m}^{3}$, so as to ensure the normal operation of subsequent equipment. The size of grille type grit chamber is $2.40 \mathrm{~m} \times 13.25 \mathrm{~m} \times 4.45 \mathrm{~m}$, while 2 sets of mechanical fine grilles are selected with the grille spacing of $5 \mathrm{~mm}$ and the power of $1.1 \mathrm{kw}$. The sand discharge pump has the flow rate of $12 \mathrm{~m}^{3} / \mathrm{h}$, head of $8 \mathrm{~m}$ and power of $0.75 \mathrm{kw}$.

(2) Lifting pump station. The sewage will be lifted to next processing unit via the pump. Its effective volume is $160 \mathrm{~m}^{3}$ and 3 sets of submersible lift pumps are selected. The pump has the flow rate of $500 \mathrm{~m}^{3} / \mathrm{h}$, head of $15 \mathrm{~m}$, power of $30 \mathrm{kw}$, and variable frequency.

(3) High-sludge sedimentation tank. The High-sludge sedimentation tank integrates the features of the coagulation tank, flocculation tank, precipitation tank and sludge thickener and may effectively remove most SS and TP, while it has a certain removal efficiency upon the pollutants. It has the size of $(7.80 \mathrm{~m} \times 6.60 \mathrm{~m}+$ $5.05 \mathrm{~m} \times 3.45 \mathrm{~m}) \times 5.50 \mathrm{~m}$. Among them, the retention time at the coagulation section is $1.5 \mathrm{~min}$ and the retention time at the flocculation section is $4.3 \mathrm{~min}$, while the surface load at the settling section is $12.5 \mathrm{~m} / \mathrm{h}$. The sludge recycle ratio is $50 \%-100 \%$, so as to increase the coagulation effect and accelerate the growth of floc and precipitation speed.

(4) Denitrification filtering tank. The Denitrification filtering tank consists of the distribution water system, distribution water pipe, backwash device, filtering media, and filtering media catcher, which utilizes the nitrification liquid backflowed from the nitrification filtering tank filtering tank to conduct the denitrification and remove most nitrate, nitrite, $\mathrm{BOD}_{5}, \mathrm{COD}$ and other pollutants in sewage. Each grille has the size of $7.30 \mathrm{~m} \times 4.00 \mathrm{~m} \times 5.70 \mathrm{~m}$, and there are 4 grilles in total. Among them, the empty bed retention time is $56 \mathrm{~min}$, and 
the effective height of filtering media is $2.5 \mathrm{~m}$. The sludge recycle ratio is $50 \%-150 \%$.

(5) nitrification filtering tank. The nitrification filtering tank consists of the distribution water system, distribution water pipe, aeration device, backwash device, filtering media, and filtering media catcher. Under the aerobic conditions, it may remove most $\mathrm{NH}_{3}-\mathrm{N}$, phosphate, and organic pollutants in sewage. Each grille has the size of $8.50 \mathrm{~m} \times 6.60 \mathrm{~m} \times 7.00 \mathrm{~m}$, and there are 5 grilles in total. Among them, the empty bed retention time is $2.8 \mathrm{~h}$, and the effective height of filtering media is $3.7 \mathrm{~m}$.

(6) Cloth media filtering tank. The suspended matter in the effluent of nitrification filtering tank will be intercepted by the cloth media and the effluent is subject to the deep removal, so as to stabilize the TP, SS and other effluent indexes. Its size is $6.00 \mathrm{~m} \times 3.00 \mathrm{~m} \times 2.20 \mathrm{~m}$, and the retention time is $2.6 \mathrm{~min}$.

(7) Ultraviolet disinfection channel. The effluent of the cloth media filtering tank will be discharged into the surrounding rivers after the ultraviolet disinfection treatment. Its size is $12.00 \mathrm{~m} \times 4.00 \mathrm{~m} \times 2.20 \mathrm{~m}$.

(8) Sludge tank. It is the area where the sludge is temporarily stored. Its size is $8.30 \mathrm{~m} \times 5.00 \mathrm{~m} \times 4.50 \mathrm{~m}$, and its effective volume is $156 \mathrm{~m}^{3}$. The lift pump station is selected to send the sludge to 2 sets of stacked screw press filters for pre-treatment. Then, the low temperature dewatering is conducted via the low-temperature dryer. The maximum handling capacity and power of stacked screw press filter are $300 \mathrm{~kg} \mathrm{DS} / \mathrm{h}$ and $3.1 \mathrm{kw}$ separately, while the low-temperature dryer may dewater the sludge to about $30 \%$.

(9) Odor treatment equipment. The odor generated at each key zones are collectively collected via the pipeline, while the air amount and pressure will be adjusted and controlled via the valves. Finally, the odor removal is collectively conducted via the biological deodorization equipment. The odor handling capacity is $10000 \mathrm{~m}^{3} / \mathrm{h}$.

The whole system has the floor area of about $2,500 \mathrm{~m}^{2}$, and the arrangement is very compact.

\section{Operation Effect Analysis}

\subsection{Operation conditions}

After the debugging and stable operation of compact type sewage treatment plant, the operation effect of biochemical treatment system is as shown in the Figure 2.

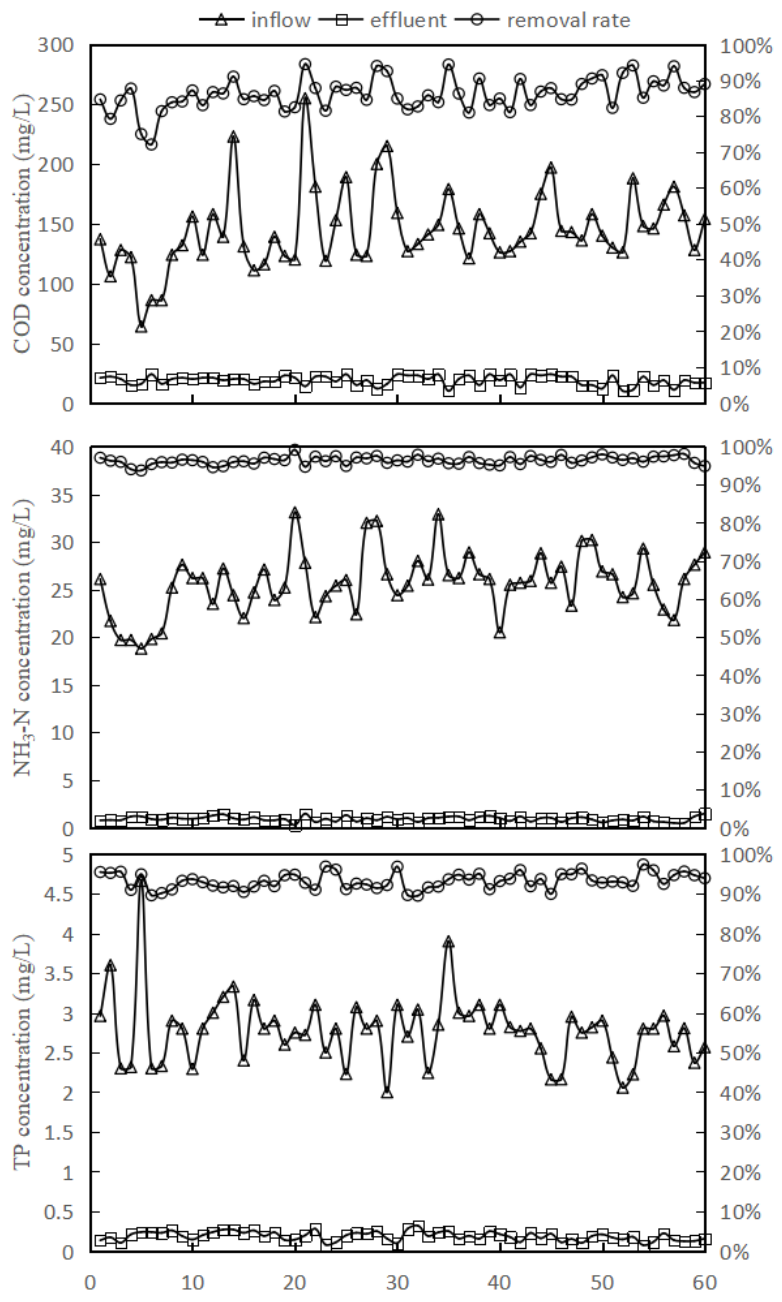

Figure 2. $\mathrm{COD}, \mathrm{NH}_{3}-\mathrm{N}, \mathrm{TP}$ concentration variations in influent and effluent 
As shown in Figure 1, after the stable operation of the system, during the $60 \mathrm{~d}$ operation process, the COD content of effluent is maintained below $30 \mathrm{mg} / \mathrm{L}$. The removal rate of the sewage treatment plant is about $87 \%$. The $\mathrm{NH}_{3}-\mathrm{N}$ content is kept below $1.5 \mathrm{mg} / \mathrm{L}$. The removal rate is about $96 \%$. The TP content is kept below $0.3 \mathrm{mg} / \mathrm{L}$. The removal rate is about $93 \%$. Therefore, the combined process "the High-sludge sedimentation tank + denitrification filtering tank + nitrification filtering tank + cloth media filtering tank" is adopted to treat the sanitary sewage, which may effectively remove variable pollutants. The effluent may reach the quasi grade IV standard of surface water.

\subsection{Operation cost analysis}

The total investment in this project is about CNY 68million, while the operation cost is about CNY 1.70 / $\mathrm{m}^{3}$. Among them, the electricity cost, labor cost, drug cost and other cost are CNY $0.95 / \mathrm{m}^{3}$, CNY $0.22 / \mathrm{m}^{3}$, CNY $0.45 / \mathrm{m}^{3}$, and CNY $0.08 / \mathrm{m}^{3}$ separately.

\section{Conclusions \& Suggestions}

(1) The combined process "the High-sludge sedimentation tank + denitrification filtering tank + nitrification filtering tank + cloth media filtering tank" is adopted to treat the sanitary sewage, which may effectively remove variable pollutants. The effluent may reach the quasi grade IV standard of surface water, while its floor area is about $2500 \mathrm{~m}^{2}$.

(2) Please further perfect the automatic level of water quality purification plant, reduce the labor intensity, enhance the technical expertise of the operators, and ensure the stability and continuity of facility operation.

\section{References}

1. WU X H, LI Y M.(2017) Effect of $\mathrm{C} / \mathrm{N}$ ratio on denitrification of denitrification filters with different filter materials[J].Chinese Journal of Environmental Engineering, 11(1):55-62.

2. HU X, ZHANG H, XU G Y, HOU H X.(2017) Performance of Advanced Denitrification in Deep Bed Denitrification Filter[J]. China Water \& Wastewater. 33(21): 13-17, 24.

3. Wang L, Wang H B, Li Y Y, Cui Y Q.(2011) Review of Densadeg Technique[J]. Environmental Science and Management. 36(6): 64-66, 92.

4. CHEN L.(2019) Application of cloth media filter in upgrading and reconstruction of municipal sewage treatment plant $[\mathrm{J}]$. Industrial Water \& Wastewater. 50(5): 48-50.

5. Zeng Y, Zhu B Y.(2019) Brief introduction of urban wastewater treatment technique[J]. Inner Mongolia Environmental Sciences. 31(7): 76, 78. 